\title{
IMPROVED LEVEL IN RESILIENCE OF ECOSYSTEM WITH CONSERVATION WATER AREA NETWORK DESIGN, (CASE STUDY OF WEST COAST SOUTH SULAWESI)
}

\author{
Ahmad Faizal*, Chair Rani, Farid Samawi dan Hamzah \\ Fakultas Ilmu Kelautan dan Perikanan, Universitas Hasanuddin \\ *ahmad.faizal@unhas.ac.id
}

\begin{abstract}
This study was intended to design network of the conservation areas having high resilience to the environmental changes. Method applied in this study was field survey method, analysis of remote sensing images, and integration of geographical information system (decision support) Marxan Model. Results of this study showed that the western coast of South Sulawesi has biophysical relationships caused by oceanographic influence particularly seawater current and highly supporting the development the network of the conservation areas with regional principle. The optimum value for the establishment of the conservation areas was 66553,13 Ha with protection target of $20 \%$ from the available ecosystems.
\end{abstract}

\section{Keyword: Resilience of Ecosystem, Network Conservation, Marxan and West Coast South Sulawesi}

\section{PENDAHULUAN}

Eksploitasi sumberdaya alam telah berlangsung sejak beratus-ratus tahun yang lalu, salah satunya adalah sumberdaya laut. Sumberdaya laut yang dimaksud adalah berbagai ekosistem seperti terumbu karang, padang lamun, mangrove dan estuaria. Sumberdaya ekosistem yang sehat mampu mendukung hasil penangkapan ikan hingga mencapai rata-rata $30 \mathrm{ton} / \mathrm{km}^{3} /$ tahun dan menjadi sumber protein hewani terbesar bagi penduduk pesisir di dunia ( Linden and Sporrong, 1999). Kekayaan ekosistem dan pemanfaatanya menjadi salah satu pemicu terjadinya degradasi ekosistem pesisir (Bryan et al. 1998; Wilkinson, 2000)

Degradasi ekosistem pesisir khususnya terumbu karang dunia disebabkan oleh 36 $\%$ dari eksploitasi sumberdaya alam, 30\% oleh pembangunan wilayah pesisir dan $34 \%$ berasal dari pencemaran (Bryan et al. 1998). Selain itu penyebab terjadinya degradasi ekosistem dunia adalah karena perubahan iklim (Almada-Villela et al. 1982).

Kerusakan ekosistem pesisir dapat diminimalisasi dengan rehabilitasi ekosistem (Bayraktarov et al. 2015), konservasi ekosistem (Coll et al. 2016), bahkan secara alami ekosistem memiliki daya resilensi (daya lenting) untuk kembali pulih seperti kondisi awal setelah mengalami gangguan dengan cara bertahan hidup ataupun dengan adaptasi dengan lingkungannya (Maynard et al. 2012).

Proses perbaikan ekosistem ini bermuara pada dibentuknya kawasan konservasi, di Jamaica pada kurung waktu 1996-1999 kawasan konservasi ikan-ikan herbivora meningkatkan pemulihan ekosisten terumbu karang dari makroalga sebesar 50\% (Williams et al. 2001). Konservasi ekosistem akan membantu resiliensi ekosistem pesisir (O'Leary et al. 2017). 
RI telah mengembangkan kebijakan kawasan konservasi dengan mengalokasikan sebagian wilayah pesisir dan laut sebagai tempat perlindungan bagi ikan-ikan ekonomis penting untuk memijah dan berkembang biak dengan baik. (Faizal et al. 2016a). Melalui PP No 60 Tahun 2007 tentang Konservasi Sumberdaya Ikan telah disusun regulasi kawasan konservasi yang terdiri dari zona inti, zona perikanan berkelanjutan, zona pemanfaatan dan zona lainnya. Faizal et al. (2012) dan Faizal et al. (2013) telah mengembakan metode pembentukan kawasan konservasi sesuai dengan PP No 60/2007 dengan Multicriteria Decision Making (MCDM dan Integrasi MCDM dengan Model Marxan.

Desain jejaring kawasan konservasi dengan analisis spasial akan meningkatkan resielensi ekosistem (Folke et al. 2004), memperkecil resiko lingkungan dan perubahan iklim (Wilson et al. 2006). Kurangnya aktivitas manusia pada kawasan konservasi akan meningkatkan keanekaragaman hayati, penurunan eksploitasi sumberdaya, pencemaran, limbah antropogenik dan penggunaan lahan (Folke et al. 2004; Peterson et al. 1998).
Daya lenting atau resielensi adalah suatu sistem untuk kembali lagi ke kondisi awal atau semula. Komponen daya lenting ada dua yaitu; Kemampuan untuk menyerap atau menahan dampak tekanan (resistance) dan kemampuan untuk pulih (recovery) (Maynard et al. 2012). Daya lenting sangat tergantung pada stabilitas ekosistem dan kemampuan menteloransi gangguan dan memulihkan diri (Peterson et al. 1998).

Pantai Barat Sulawesi Selatan dikenal dengan keanekragaman ekosistem dengan beberapa kawasan konservasi yang terpencar. Sehingga perlu adanya pengelolaan kawasan konservasi dengan desain jejaring kawasan konservasi perairan, metode yang gunakan adalah model marxan ( Ball and Possinghmam., 2000). Penelitian ini bertujuan mendesain jejaring kawasan konservasi yang memiliki daya lenting yang tinggi terhadap perubahan lingkungan.

\section{METODE PENELITIAN}

Waktu dan Tempat. Penelitian dilaksanakan di Pantai Barat Provinsi Sulawesi Selatan (Gambar. 1) dan analsis data di Laboratoium Penginderaan Jauh dan Sistem Informasi Geografis Kelautan, Fakultas Ilmu Kelautan dan Perikanan, Universitas Hasanuddin. Penelitian dilaksanakan selama 2 (dua) tahun 20152017

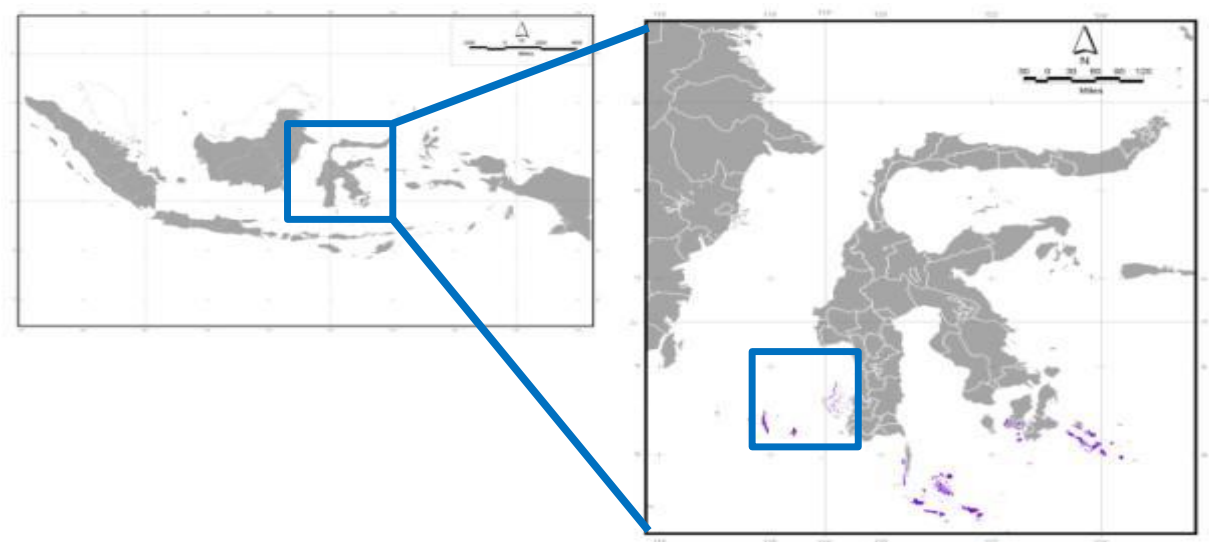

Gambar 1. Lokasi Penelitian Pantai Barat Provinsi Sulawesi Selatan 


\section{Metodologi dan Analisis Data}

Skema penelitian dengan meggunakan model marxan (Gambar 2). Pada skema tersebut menggunakan data bio-ekologi (Faizal et al. 2016a), data hidro-oseanografi dengan pengukuran arah dan kecepatan arus menggunakan data mooring ACDP (Faizal et al. 2016b), data sosial ekonomi didapatkan dari hasil wawancara di tiga Kabupaten dan pulaupulau kecil dan data kondisi perairan laut dalam dengan metodologi survei (Faizal et al. 2016b)

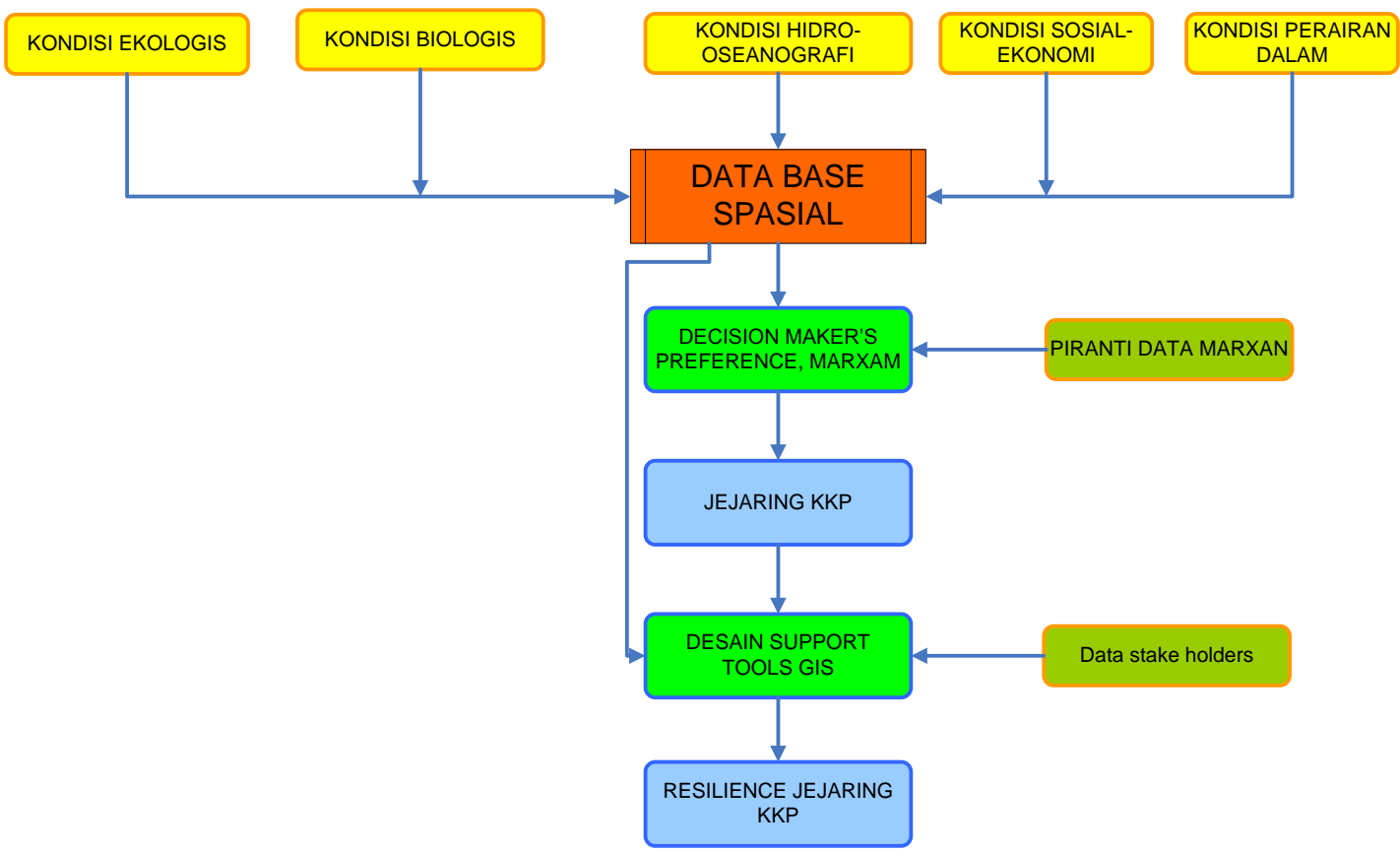

Gambar 2. Diagram alir penelitian

Analisis data dengan menggunakan analisis berbasis spasial, keseluruhan data disusun dalam sebuah model data spasial yang berbasis point, line dan polygon. Setiap data disertai dengan atribut-atribut sesuai dengan kebutuhan analisis. Data yang tersusun dalam bentuk database dianalisis dengan piranti marxan dengan tahapan seperti pada Gambar 3.

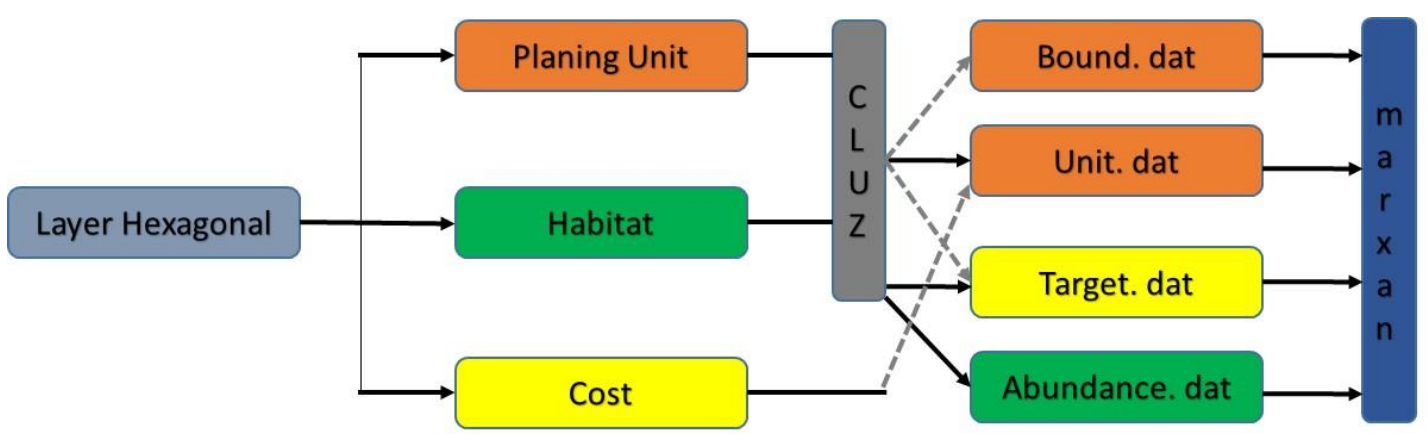

Gambar 3 Tahapan analisis spasial dengan model marxan (Meerman C. J., 2005) 
Adapun tahapan persiapan dan konfigurasi data marxan sebagai berikut :

- Layer Hexagonal : Peyusunan frame data dalam bentuk data hexagonal.Planning Unit (PU) : Unit Pengelolaan sebagai basis data Marxan dalam bentuk model ekosistem (Meerman, C.J, 2005). Data spasial disusun dalam bentuk peta-peta tematik sesuai batas wilayah kajian.

- Habitat : Data spasial habitat diturunkan dari data PU yang dikombinasikan dengan data sebaran ekosistem hasil interpetasi citra satelit.

- Cost : adalah biaya yang dibutuhkan dan faktor resiko dalam penyusunan kawasan konservasi dengan persamaan :

\section{Total Biaya $=$ Biaya unit \\ perencanaan + (biaya batas unit * BLM) + Faktor Pinalti (SPF) \\ Di mana yang dimaksud dengan} Biaya Unit Perencanaan adalah Setiap unit perencanaan diberi nilai biaya, berdasarkan daerah, nilai keuangan, biaya kesempatan itu dilindungi (pendapatan yang hilang misalnya dari pertanian) atau faktor lain yang relevan. Biaya Unit Batas (BLM) adalah Biaya batas mengukur jumlah tepi bahwa unit-unit perencanaan di bagian portofolio dengan unit terlindungi. Biaya adalah dihitung sebagai panjang tepi dalam meter, kilometer atau sistem pengukuran lain. Dan faktor Finalti (SPF) adalah pemberian finalti bagi faktor yang tidak terpenuhi.
CLUZ : adalah paket program untuk konfigurasi data Marxan yang meliputi data Abundance (Atribut Fitur Konservasi), Data Target (Target ouput fitur konservasi, Unit Data (Pembatasan Area yang akan di analisis) dan Bound Data (Informasi Panjang batas untuk Planning Unit yang berdekatan.

\section{HASIL DAN PEMBAHASAN}

\section{Kondisi Eksiting Kawasan Konservasi di Pantai Barat Sulawesi Selatan}

Berdasarkan analisis data sekunder dari berbagai sumber BKKPN Kupang (2013), BPSPL (2014) perairan pantai barat Sulawesi Selatan terdapat kawasan konservasi eksisting, baik yang sifatnya lokal maupun yang bersifat nasional. Pada wilayah pantai barat Sulawesi Selatan terdapat satu Taman Wisata Perairan (TWP) Kapoposang berdasarkan SK Menteri Kelautan dan Perikanan (KEP. 66/MEN/2009 ) dengan luas kawasan $50000 \mathrm{Ha}$ dan yang kedua Kawasan Konservasi Perairan Daerah (KKPD) berdasarkan Peraturan Bupati Pangkajenne Kepulauan (Pangkep) Nomer 180/2009 dengan luas kawasan $66870 \mathrm{Ha}$ seperti pada Gambar 4. Secara detail luas kawasan masing zona untuk TWP dan KKPD Kabupaten Pangkep seperti pada Tabel 1. 


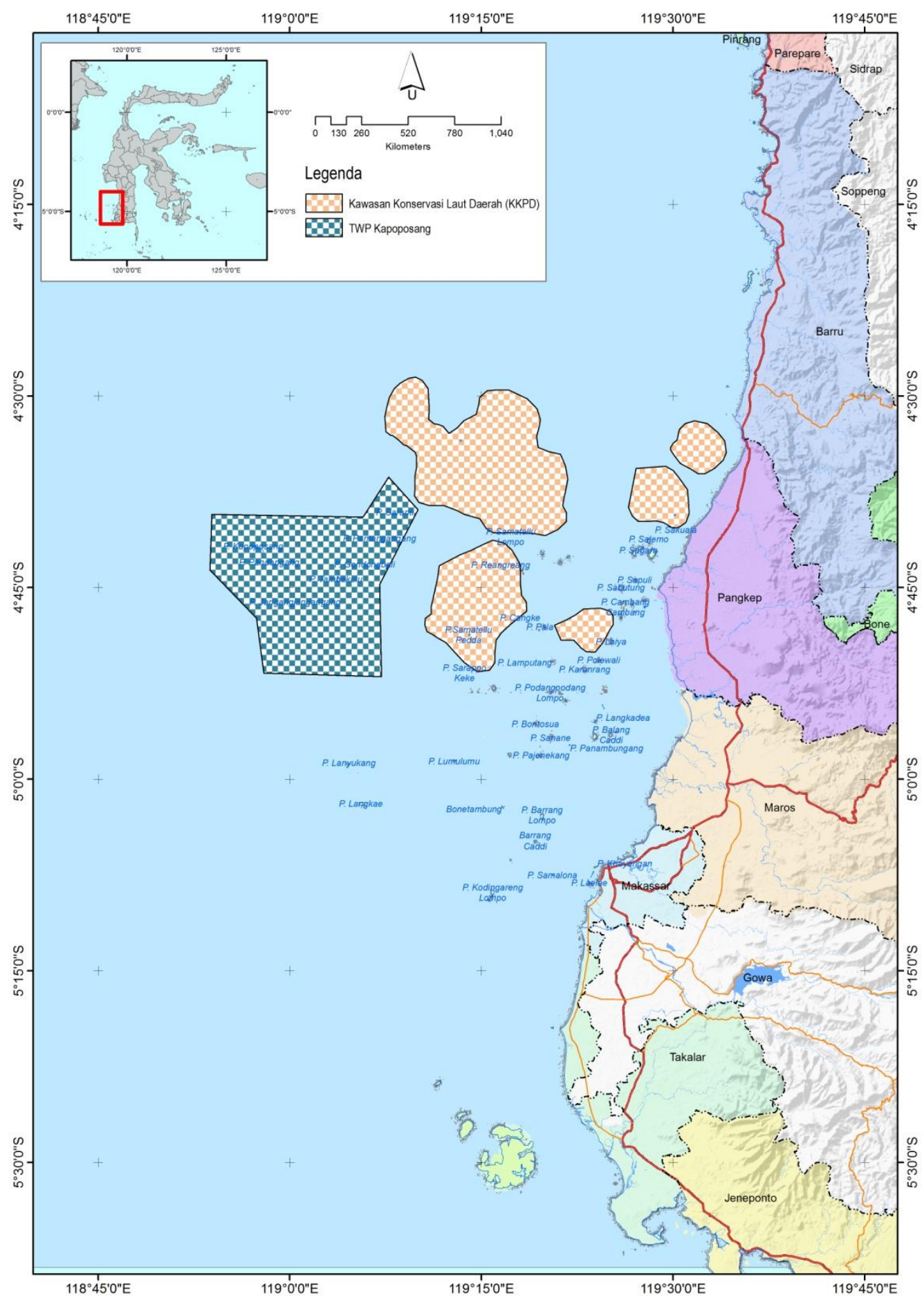

Gambar 4. Kondisi Terkini Kawasan Konservasi Pantai Barat Sulawesi Selatan. (sumber : hasil pengolahan data spasial; BKKPN Kupang 2013, dan BPSPL, 2014) 
Tabel 1. Luas masing-masing zona TWP Kapoposang dan KKPD Kabupaten Pangkep.

\begin{tabular}{lrr}
\hline \multicolumn{1}{c}{ Zona Kawasan Konservasi } & TWP Kapoposang & KKPD Pangkep \\
\hline Zona Inti (Ha) & 1086,87 & 24888,69 \\
Zona Perikanan Berkelanjutan (Ha) & 39340,3 & 83869,25 \\
Zona Pemanfaatan (Ha) & 6123,0 & 53274,62 \\
Zona Lainnya (Ha) & - & 9905,14 \\
Zona Penangkapan Tradisional (Ha) & 3414,0 & 171937,70 \\
Total Luas (Ha) & 50000 & 14,4 \\
Persentase Zona Inti (\%)
\end{tabular}

Data tersebut memperlihatkan bahwa total luas kawasan konservasi di perairan pantai barat Sulawesi Selatan adalah 221937,7 Ha dengan luas zona inti (non take zone) sebesar $11 \%$. Secara hitungan ideal maka luas zona inti masih dibawa dari standart $20 \%$ dari total luas kawasan konservasi.

\section{Identifikasi Kawasan Konservasi dengan Marxan}

Pemenuhan kawasan konservasi berdasarkan target pemerintah dengan kisaran 20-30\% daerah ekosistem sebagai kawasan konservasi (zona inti), maka perlu dikembangkan jejaring kawasan konservasi.
Hasil analisis marxan dengan 3 (tiga) skenario untuk mencapai target $20 \%$ wilayah habitat untuk konservasi dengan skenario Boundary Lenght Modifer (BLM) yaitu; $\quad B L M=0,1, \quad B L M=0,25$ dan $\mathrm{BLM}=1$.

Hasil analisis skenario BLM seperti pada Tabel 2, potensi luas kawasan konservasi yang terbesar adalan BLM 0,25 atau skenario 2 dengan luas kawasan 66553,13 Ha. Sedangkan yang terburuk adalah BLM 1 (skenario 3) dengan potensi luas kawasan konservasi 42798,26 Ha. Sebaran lokasi kawasan masing-masing skenaria ditampilkan pada Gambar 5, Gambar 6 dan Gambar 7.

Tabel 2 . Hasil analisis marxan best selection pemanfaatan kawasan konservasi.

\begin{tabular}{|c|c|c|c|}
\hline \multirow[b]{2}{*}{ Skenario /Target $20 \%$} & \multicolumn{3}{|c|}{ Potensi Kawasan Konservasi (Ha) } \\
\hline & $\begin{array}{l}\text { Terumbu karang dan } \\
\text { Lamun }\end{array}$ & Mangrove & Total \\
\hline BLM 0,1 & 64365,53 & 1294,06 & 65659,59 \\
\hline BLM 0,25 & 65539,26 & 1013,87 & 66553,13 \\
\hline BLM 1 & 42647,61 & 150,65 & 42798,26 \\
\hline
\end{tabular}




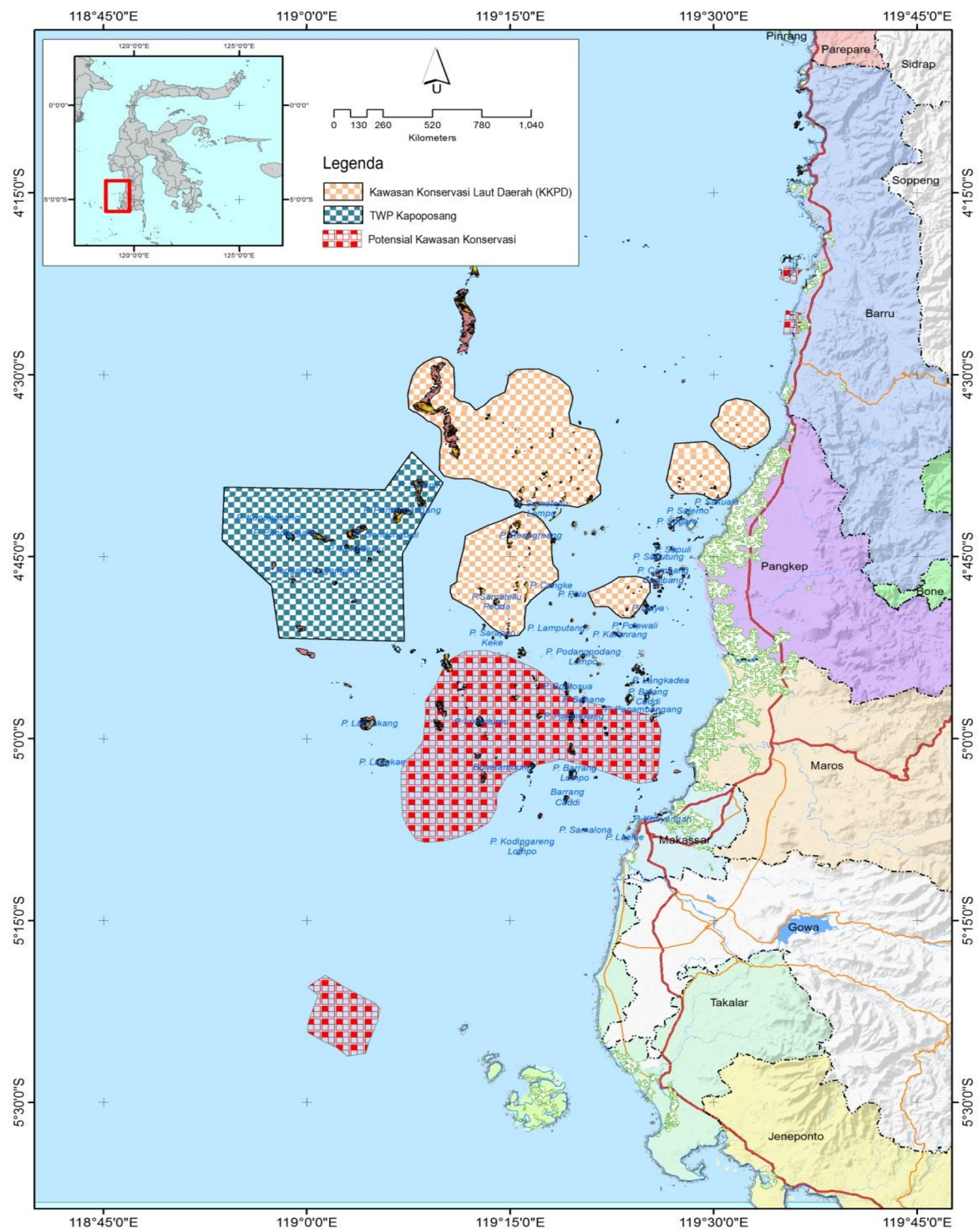

Gambar 5. Lokasi Potensial untuk pengembangan kawasan konservasi dengan skenario BLM=0,1 (sumber : hasil pengolahan data spasial) 


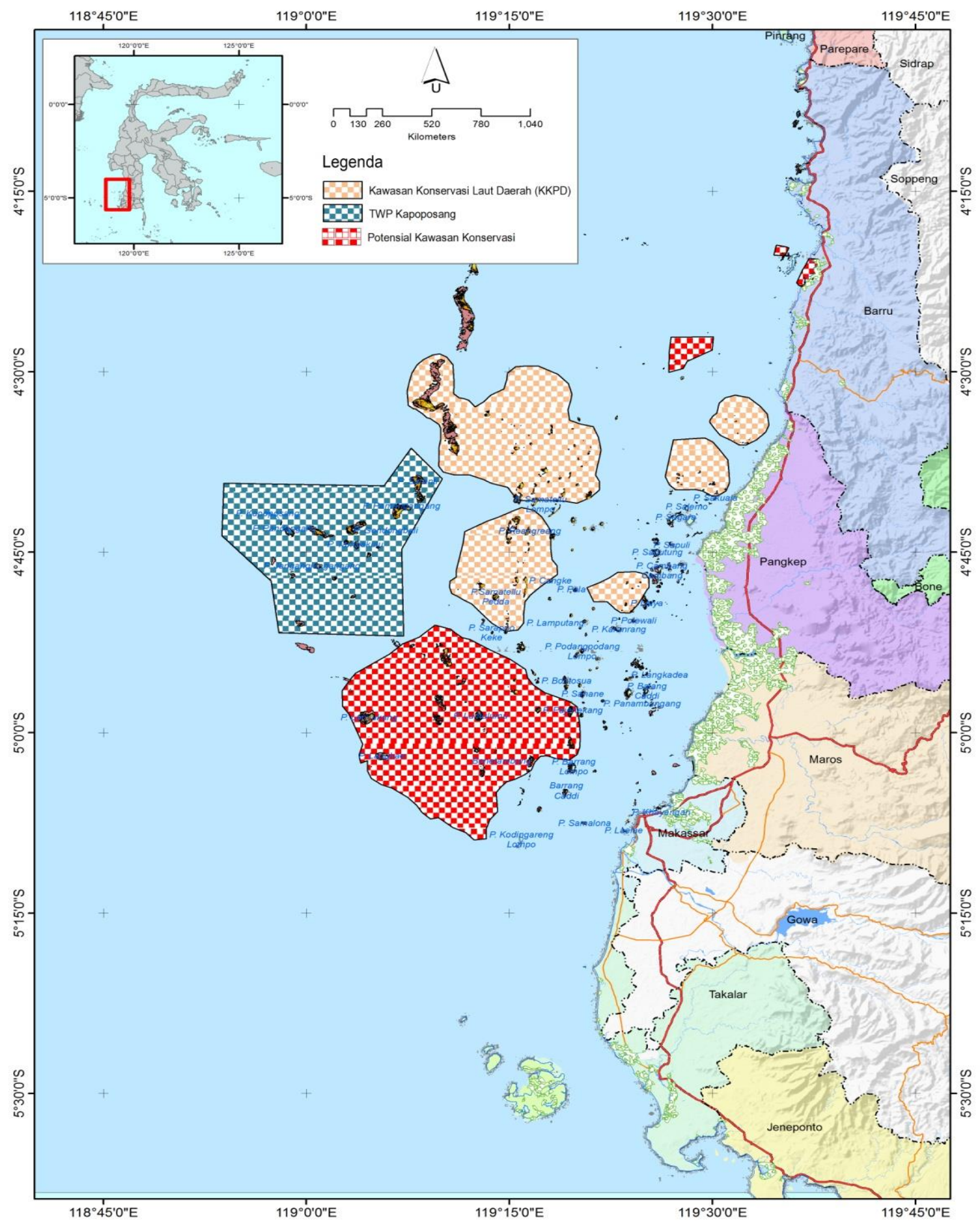

Gambar 6. Lokasi Potensial untuk pengembangan kawasan konservasi dengan skenario BLM=0,25 (sumber : hasil pengolahan data spasial) 


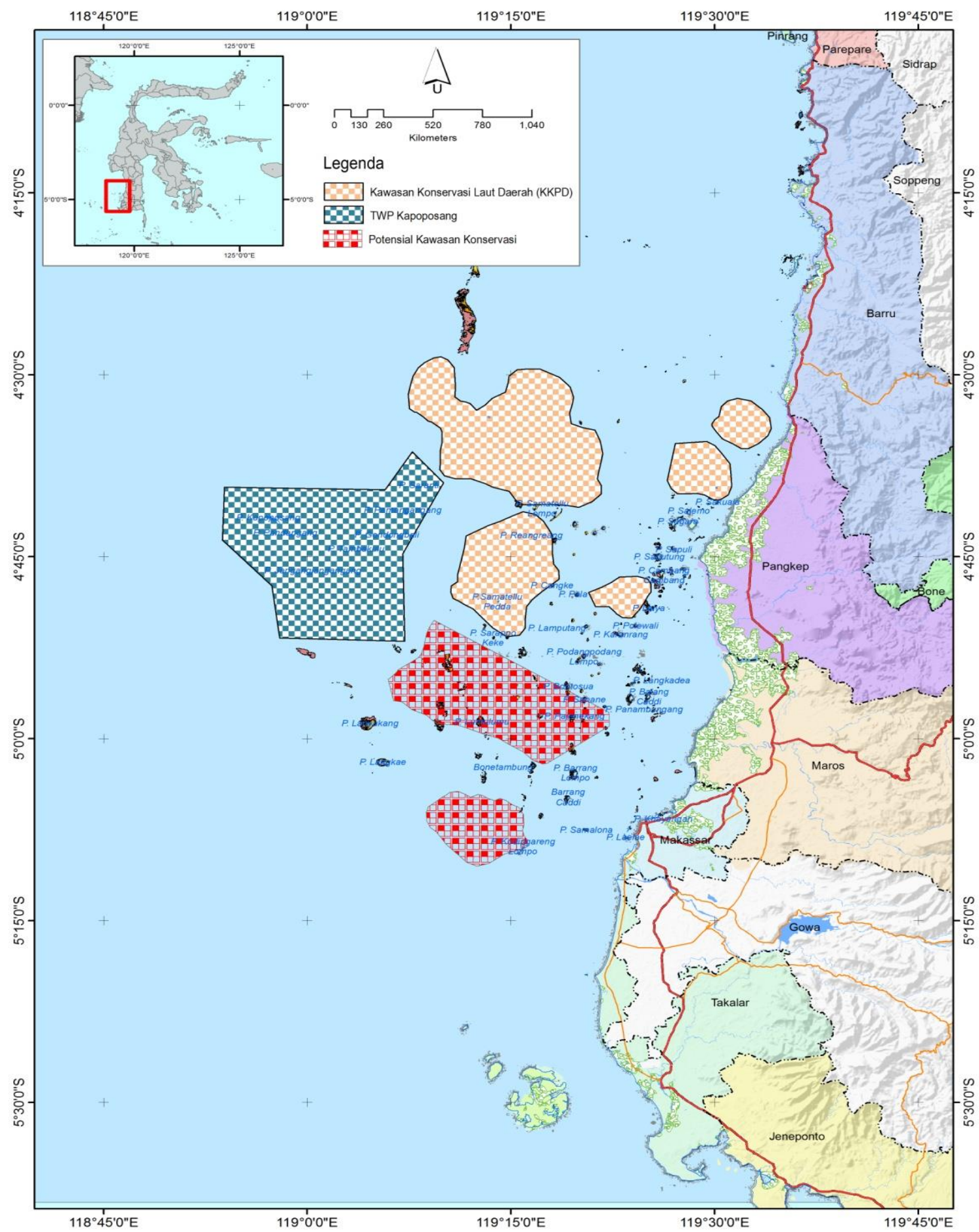

Gambar 7. Lokasi Potensial untuk pengembangan kawasan konservasi dengan skenario $\mathrm{BLM}=1$ (sumber $:$ hasil pengolahan data spasial)

Model Pengembangan Jejaring Kawasan Konservasi untuk Peningkatan Resilence
Berdasarkan atas PP No 60 Tahun 2007 tentang Konservasi Sumberdaya Ikan bahwa pengembangan kawasan konservasi 
untuk meningkatkan daya lenting ekosistem dapat di lakukan dengan beberapa pertimbangan sebagai berikut :

- Keterwakilan habitat, adalah pemilhan habitat penting sebesar $20-30 \%$ dari luas ekosistem yang ada

- Daerah kritis : fokus alokasi ruang untuk kawasan konservasi pada daerah-daerah tempat bertelur, pemijahan dan habitat yang tahan terhadap perubahan ekosistem.

- Keterkaitan : adanya konektivitas antara satu lokasi dengan lokasi lain.

- Jarak antara kawasan dekat untuk memudahkan pengelolaan

Berdasarkan atas kondisi dan kriteria yang ada maka pemilihan skenario terbaik untuk peningkatan resilensi adalah skenario II $(B L M=0,25)$ dengan pengaturan seperti pada Gambar 8. Pengaturan kawasan jejaring kawasan konservasi peraiaran di wilayah barat Sulawesi Selatan selain kondisi eksisting (TWP Kapoposang) dibagi atas 3 kelompok pengelolaan. Kelompok pertama adalah bagian utara kawasan yang meliputi wilayah Pulau
Panikiang, Pantai Malusetasi dan Gusung Torajae untuk konservasi karang dan lamun serta Pulau Sabangko untuk perlindungan Mangrove. Kelompok kedua adalah kelompok perlindungan karang dan lamun pada daerah semi tertutup meliputi pulau-pulau disekitar Reang-reang dan Bontosua. Kelompok ketiga adalah adalah kelompok perlindungan karang khususnya pada daerah yang terbuka dengan laut lepas yang meliputi wilayah Pulau Lumu-lumu dan gusung sekitarnya.

Pengelompokan kawasan ini sangat sesuai dengan teori efek tepi (Ball and Possinghmam, 2000). Semakin terbukanya suatu lokasi kawasan konservasi maka lokasi tersebut semakin rentang akan terjadinya kerusakan ekosistem. Pertimbangan lainnya pengelompokan yang dilakukan dengan meminimalkan jarak keliling dari kawasan, dengan mengecilnya keliling dari kawasan maka juga akan meminimalkan biaya pengelolaan dan hal yang sama telah dilakukan oleh Meerman (2005). 


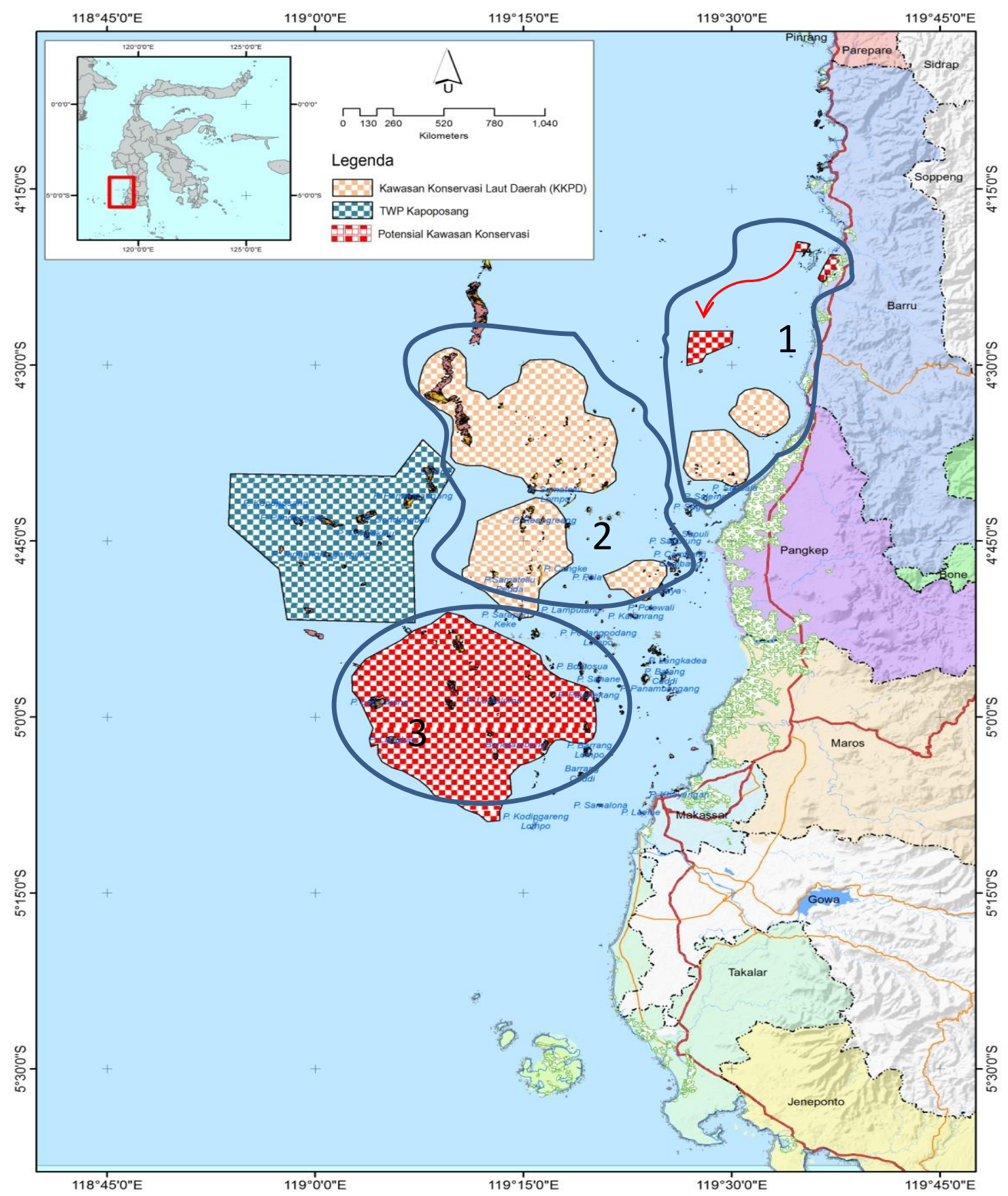

Gambar 8. Model jejaring kawasan konservasi di Perairan Barat Sulawesi Selatan (sumber : hasil pengolahan data spasial)

\section{KESIMPULAN}

1. Skenario model marxan terbaik yang dihasilkan adalah skenario dengan BLM 0,25 .
2. Solusi pengembangan kawasan konservasi perairan dengan berdasarkan prinsip resiliensi dan target kawasan konservasi $20 \%$ adalah seluas 66553,13 Ha. 


\section{DAFTAR PUSTAKA}

1. Almada-Vilela, P.C. John, D and Lylr D G. 1982. The effects of temperature on the growth of young mytilus edulis. L. Journal of Experimental Marine Biology and Ecology. 59(2-3) 275288.

2. Badan Informasi Geospaial (BIG), 2015. Peta Digital Rupa Bumi Indonesia. Jakarta.

3. Balai Pengelolaan Sumberdaya Pesisir dan Laut (BPSPL), 2014. Situs Selam di Kapaoposang. Kementeraian Kelautan dan Perikanan, Direktorat Jenderal Kelautan, Pesisir dan Pulau-pulau kecil. Jakarta. 30 hal.

4. Balai Kawasan Konservasi Perairan Nasional (BKKPN) Kupang, 2013. Pemantauan Kondisi Biofisik Di 7 (Tujuh) Kawasan Kawasan Konservasi Perairan Nasional Wilayah Kerja Balai Kawasan Konservasi Perairan Nasional. Kementeraian Kelautan dan Perikanan, Direktorat Jenderal Kelautan, Pesisir dan Pulau-pulau kecil. Jakarta. 455 hal.

5. Ball, I. R. and H. P. Possingham, (2000) MARXAN (V1.8.2): Marine Reserve Design Using Spatially Explicit Annealing, a Manual.

6. Bayraktarov, E, Saunders, M.I, Abudullah, S., Mills, M., M. Beher, J., Possigham, H, P., . Mumby. P.J And Lovelock C.E. 2015. The Cost and feasibility of marine coastal restoration. Ecological Application. 26 (4) 1055-1074.

7. Bryant D., Burke L., McManus J. and Spalding M., 1998. Reefs at risk: A map basedindicator of threats to the world's coral reefs. World Resources Institute Report, WRI/ICLARM/WCMC/UNEP, Washington.

8. Coll, M., Shannon, L, J., Kleisner, K.M., Juan-Jorda, M, J., Bundy, A., Akoglu A.G., Banaru, D., Boldth, J, L., Borges,.M, F., Cook, A., Diallo, I., Fu, C., Fox, C., Gascuel, D., Gurney, L.J, Hattab, T,. Heymans, J.J, Jouffre, D and Shin, Y.J. 2016. Ecological indicators to capture the effects of fishing on biodiversity and conservation status of marine ecosystems, Ecological Indicators ; 60 , 947-962.

9. Faizal, A. Natsir Nessa, Jamaluddin Jompa, Chair Rani dan Rohani, 2012. Pengembangan MCDM berbasis SIG dalam penentuan Kawasan Konservasi Perairan. Laporan Penelitian Hibah Program Studi, Lembaga Penelitian dan Pengabdian Masyarakat. UNHAS.

10. Faizal, A. Chair Rani, Samad W. Nurjanna 2013. Integrasi Marxan dan Multikriteria Decision Making berbasis SIG untuk penentuan kawasan konservasi daerah. Laporan Penelitian Hibah Komptetnsi Internal. Lembaga Penelitian dan Pengabdian Masyarakt, UNHAS.

11. Faizal A., Rani, C., Samawi, F., dan Hamzah, 2016a. Studi Awal; Desain Jejaring Kawasan Konservasi di Pantai Barat Sulawesi Selatan. Spermonde 2(2): 6-12.

12. Faizal A., Rani, C., Samawi, F., dan Hamzah, 2016b. Desain Jejaring Kawasan Konservasi Perairan Untuk Peningkatan Tingkat Resiliensi Di Pantai Barat Sulawesi Selatan. Laporan Hasil Penelitian Hibah Unggulan Perguruanb Tinggi, Lembaga Penelitian dan Pengabdian Masyarakat. Univesitas Hasanuddin. 104 hal.

13. Folke, C., Carpenter, S., Walker, B., Scheffer, M., Elmqvist, T., Gunderson, L., Holling, C.S. 2004. "Regime Shifts, Resilience, and Biodiversity in Ecosystem Management". Annual Review of Ecology, Evolution, and Systematics 35: 557-581.

14. Linden, O. and Sporrong, N. 1999. Coral reef degradation in the Indian Ocean: status reports and project presentations. Food and agriculture Organizationof the United Nations.

15. Maynard J, Wilson J, Campbell S, Mangubhai S, Setiasih N, Sartin J,Ardiwijaya R, Obura D, Marshall P, Salm R, Heron S, and Goldberg J. 2012. Assessing coral resilience and bleaching impacts in the Indonesian archipelago. Technical Report to The Nature Conservancy with contributions from Wildlife Conservation Society and Reef Check Indonesia. 62 pp.

16. Meerman,C.J, 2005. Protected areas system assessment and analysis; Marxan Analysis. Protected Area Policy and System Plan, Beliz. http://biologicaldiversity.info/Downloads/NPAPSP/MARXANanalysis.pdf (di akses Juli 2018).

17. O'Leary, E,K., Micheli, F., Airoldi, L. Charles Boch, C., Leo, G, D., Robin Elahi, R., Ferretti, F., Nicholas A, J., Graham Steven Y. L., Natalie H. Low, Lummis, S., Kerry J. and 
Wong, J.,N 2017. The Resilience of Marine Ecosystems to Climatic Disturbances , BioScience, 67, (3) 208-220

18. Peterson, G., Allen, C.R., Holling, C.S. (1998). "Ecological Resilience, Biodiversity, and Scale". Ecosystems 1 (1): 6-18.

19. Williams ID, Polunin NVC, and Hendrick VJ. 2001. Limits to grazing by herbivorous fishes and the impact of low coral cover on macroalgal abundance on a coral reef in Belize. Mar Ecol Prog Ser 222: 187-196.

20. Wilkinson C.R. (ed), 2000. Status of Coral Reefs of the World: 2000. Australian Institute of Marine Sciences, Townsville.

21. Wilson, Kerrie, McBride, Marissa, Bode, Michael, Possingham, Hugh. (2006). Prioritizing global conservation efforts. Nature. 440. 337-40. 10.1038/nature04366.

22. PP No 60 tahun 2007. Tentang Konservasi Sumberdaya Ikan. http://www.ppkkp3k.kkp.go.id/ver3/media/download/RE_peraturan-pemerintah-republik-indonesia-nomor-60tahun-2007_20141007154109.PDF (diakses, Juli 2018).

23. http://www.kent.ac.uk/dice/cluz/marxan1.htm (diakses, November 2016). 